\title{
Atopic dermatitis and vitamin D: facts and controversies
}

\author{
Dermatite atópica e vitamina D: fatos e controvérsias
}

\author{
Kleyton de Carvalho Mesquita ${ }^{1}$ \\ Izelda Maria Carvalho Costa ${ }^{3}$
}

Ana Carolina de Souza Machado Igreja²

DOI: $h$ ttp://dx.doi.org/10.1590/abd1806-4841.20132660

\begin{abstract}
Patients with atopic dermatitis have genetically determined risk factors that affect the barrier function of the skin and immune responses that interact with environmental factors. Clinically, this results in an intensely pruriginous and inflamed skin that allows the penetration of irritants and allergens and predisposes patients to colonization and infection by microorganisms. Among the various etiological factors responsible for the increased prevalence of atopic diseases over the past few decades, the role of vitamin D has been emphasized. As the pathogenesis of $\mathrm{AD}$ involves a complex interplay of epidermal barrier dysfunction and dysregulated immune response, and vitamin D is involved in both processes, it is reasonable to expect that vitamin D's status could be associated with atopic dermatitis' risk or severity. Such association is suggested by epidemiological and experimental data. In this review, we will discuss the evidence for and against this controversial relationship, emphasizing the possible etiopathogenic mechanisms involved.
\end{abstract}

Keywords: Defensins; Dermatitis, atopic; Vitamin D; Vitamin D Deficiency

Resumo: Pacientes com dermatite atópica têm fatores de risco geneticamente determinados que afetam a função de barreira da pele e as respostas imunes, as quais interagem com fatores ambientais. Clinicamente, isso resulta em uma pele intensamente pruriginosa, inflamada, que permite a penetração de irritantes e alérgenos e predispõe os pacientes à colonização e à infecção por micro-organismos. Dentre os diversos fatores etiológicos responsáveis pelo aumento da prevalência de doenças atópicas nas últimas décadas, o papel da vitamina $\mathrm{D}$ tem ganhado destaque. Uma vez que a patogênese da dermatite envolve uma interação complexa da disfunção da barreira epidérmica e desregulação da resposta imune - e a vitamina D está envolvida em ambos os processos-, é razoável esperar que a vitamina $\mathrm{D}$ esteja associada ao risco ou à gravidade da dermatite atópica. Tal associação é sugerida por dados epidemiológicos e experimentais. Nessa revisão, serão abordadas as evidências favoráveis e contrárias a essa polêmica relação, enfatizando os possíveis mecanismos etiopatogênicos envolvidos.

Palavras-chave: Defensinas; Deficiência de vitamina D; Dermatite atópica; Vitamina D

\section{INTRODUCTION}

Atopic dermatitis (AD), a common chronic inflammatory dermatosis, is clinically distinguished by pruritus, eczematous plaques and a defective epidermal barrier. Considered the earliest manifestation of atopy, it affects preferably children, the majority of which evolve with remission in adulthood. Nevertheless, the disease may persist in more than $10 \%$ of these patients until adolescence or adulthood..$^{1-5}$ Global evidences reflect a marked increase in prevalence, which has tripled since 1960. In the United States, the current prevalence rates range from $10 \%$ to $20 \%$ in children and 1 to $3 \%$ in adults. ${ }^{6}$ There is little data on the prevalence of this disease in Brazil.
New discoveries about genetics and pathophysiology of AD point to an important role of structural abnormalities in the epidermis, as well as changes in the immune system. Environmental factors and other unidentified aspects may influence the expression of the disease. The etiopathogenesis of $\mathrm{AD}$ is therefore complex and not yet fully elucidated..$^{5}$

Vitamin D - classically associated to bone metabolism and calcium homeostasis - was also identified as a steroid hormone, and several studies now emphasize its action on extra skeletal health. Research linking vitamin D deficiency to an increased risk of malignancies (especially colorectal), atopic diseases, autoimmune, infectious and, cardiovascular disor-

Received on 31.03.2013.

Approved by the Advisory Board and accepted for publication on 03.04.2013.

* Work performed at the Brasilia University Hospital Dermatology Service - University of Brasilia (HUB/UNB) - Brasília (DF), Brazil.

Financial Support: None

Conflict of Interest: None

MD, PhD (in course) in Health Sciences - University of Brasilia (UNB) - Dermatologist at the Federal District Health State Department (SES-DF) - Brasilia (DF), Brazil.

MD, Dermatologist - Residency in Dermatology at the Brasilia University Hospital - University of Brasilia (HUB-UNB) - Brasília (DF), Brazil

MD, PhD in Dermatology at São Paulo Federal University (UNIFESP) - Adjunct Professor of Dermatology at the University of Brasilia (UNB). Chief of the

Pediatric Dermatology Clinic at Brasilia University Hospital - University of Brasilia (HUB/UNB) - Brasília (DF), Brazil. 
ders, hypertension, metabolic syndrome, neuropsychiatric symptoms and mortality, is noteworthy. ${ }^{7}$

Hypovitaminosis D is increasingly found in developing countries. The prevalence of this condition varies widely between regions, reaching alarming rates of $30-90 \%$, depending on the cutoff point used. The reference values to stratify between normal, insufficient and deficient are controversial and far from being settled. ${ }^{8}$ It is estimated that 3 out of 4 Americans and 1 billion people worldwide have vitamin D insufficiency. ${ }^{9,10}$

For this review, a PubMed search was performed using the keywords "atopic dermatitis" and "vitamin D" in addition to "hypovitaminosis D". The search was restricted to articles published in English, with no date limitation. Depending on the content of abstracts, manuscripts of interest were selected and included in this review. References of these manuscripts were also evaluated in search for relevant papers. Finally, reviews and publications about this theme, found in the digital library of the authors, were also used.

\section{ATOPIC DERMATITIS}

$\mathrm{AD}$ is a chronic inflammatory disease highly itchy that often manifests itself during infancy or childhood and may persist or begin in adulthood. It can arise as the first clinical manifestation of childhood's atopic diseases. An "atopic march" occurs early in children with AD: more than 50\% develop asthma and / or allergies, usually around the age of $3 .^{11}$ Because of its chronic and pruritic nature, $\mathrm{AD}$ may have greater impact on the quality of life than asthma, diabetes, cystic fibrosis and enuresis. ${ }^{6,12-14}$ Because of its chronic itching and pain, it may cause depressive symptoms, social isolation and self-perception disorders. ${ }^{15}$

DA diagnosis is clinical, through established criteria defined by Hanifin \& Rajka (1980), ${ }^{16}$ which are classified in major and minor. To achieve the diagnosis, 3 criteria of each category are necessary (Chart 1 ).

\section{ETIOPATHOGENESIS}

AD was, for a long time, considered a dysfunction of keratinocytes. However, over the past two decades, with advances in the understanding of its pathogenesis, it has also become regarded as an immune dysregulation disorder. New concepts have emerged, demonstrating immunological and inflammatory dysfunctions, besides the importance of environmental factors. ${ }^{4,77,18}$

Although about $70 \%$ of $\mathrm{AD}$ patients have a family history of atopy, such as asthma and allergic rhinosinusitis, its prevalence varies between countries and even in regions within the same country. Studies indicate a higher incidence and prevalence in westernized and developed countries. Thus, environmental factors - including sun exposure, hygienic and dietary habits exert a crucial role in the expression of atopic manifestations. It is possible that early exposure to microorganisms, common in developing countries, contributes to the immune system maturation, reducing the incidence of $\mathrm{AD}$. It is believed, though, that the contact with microorganisms by fecal-oral route has greater protective effect than via respiratory route.

Patients with $\mathrm{AD}$, due to their impaired immunity, have a unique predisposition for colonization and infection by microorganisms, especially Staphylococcus aureus and Herpes simplex virus. S. aureus can be detected in $90 \%$ of the lesions and it can colonize apparently healthy skin in AD. This pathogen potentially exacerbates or contributes to a persistent inflammation in the skin of AD patients by secreting toxins with super antigenic properties, leading to the activation of $\mathrm{T}$ cells and other immune cells. ${ }^{5,19}$

ChART 1: Atopic dermatitis diagnostic criteria

\begin{tabular}{|l|}
\hline Major Criteria \\
Pruritus \\
Typical morphology and distribution: adults (flexor surfa- \\
ces); children and infants (face and extensor surfaces) \\
Chronic recidivating dermatitis \\
Personal or familial history of atopy \\
Minor Criteria \\
Xerosis \\
Ichthyosis / Keratosis pilaris / Palmar hyperlinearity \\
Positive cutaneous reactivity \\
Elevated serum IgE \\
Early age of onset \\
Tendency to skin infections \\
Dermatitis in hands and feet \\
Nipple eczema \\
Cheilitis \\
Conjunctivitis \\
Dennie-Morgan line \\
Keratoconus \\
Anterior subcapsular cataracts \\
Periorbital darkening \\
Facial pallor / facial eryhema \\
Pityriasis alba \\
Skin folds in the anterior region of the neck \\
Sweat-induced pruritus \\
Intolerance to wool and lipidic solvents \\
Perifollicular accentuation \\
Food intolerance \\
Environmental or emotional factors altering the course of \\
disease \\
White dermographism \\
\hline
\end{tabular}


Local and systemic immune dysregulations characterize AD. The relationship between the innate and adaptive immune responses in $\mathrm{AD}$ patients remains to be clarified. The cutaneous inflammation displays a biphasic pattern of $\mathrm{T}$ cell activation. The predominance of Th2 cytokines in the acute phase of lesion development (especially IL-4 and IL-13), which influence the synthesis of IgE and expression of adhesion molecules, is characteristic. The death of S. aureus by keratinocytes in patients with $\mathrm{AD}$ is significantly inhibited by IL-4 and IL-13. The majority of $\mathrm{AD}$ patients have elevated IgE levels, which are correlated with clinical criteria of disease severity. During the chronic phase of $\mathrm{AD}$, there is a shift to Th1 pattern, with production of interferon-gamma., ${ }^{4,520,21}$

The genetic, environmental, immunological and infectious interactions that lead to an atopic phenotype expression are not yet fully understood. ${ }^{6}$ Genomic studies suggest a probable polygenic inheritance. There is, however, relatively low concordance of $\mathrm{AD}$ incidence between monozygotic twins, indicating the multi-causal pathogenesis that influences the risk of developing a disease and its clinical manifestations.

It is believed that $A D$ patients carry specific genes that play an important role together with "generic" atopy genes. ${ }^{5}$ In a large cohort study, the risk of a child having AD was greater when one or both parents had AD (OR: 3.4, 95\% CI 2.6 to 4.4) compared with the risk when parents had asthma (OR: 1.5, 95\% CI 1.0-2.2) or allergic rhinitis (OR: 1.4, 95\% CI 1.1-1.8). ${ }^{22}$

Studies have identified several genes associated with $\mathrm{AD}$, but none of them was conclusively identified as the specific locus or gene. The identified genes encode proteins involved predominantly in the skin barrier function, especially filaggrin - as well as the innate and adaptive immune responses. ${ }^{5}$

Abnormalities in tight junctions have also been studied. It has been demonstrated that healthy epithelium, in patients with $\mathrm{AD}$, has bioelectric abnormalities indicative of tight junction defects that may be the result of decreased levels of claudin-1 (CLDN1), an adhesion protein. ${ }^{23}$

\section{VITAMIN D - KNOWLEDGE IN CONSTRUC- TION}

Vitamin D is a liposoluble vitamin synthesized mainly in the skin. When there is ultraviolet $B$ radiation (UVB) exposure, 7-dehydrocholesterol is converted to vitamin D3 (cholecalciferol). Vitamin D can also be obtained through foods and supplements [Vitamin D2 (ergocalciferol) or D3]. The skin is not able to synthesize vitamin D2. ${ }^{24}$

Vitamin D increases intestinal calcium absorption, being thus related to bone metabolism. Its deficiency in children leads to rickets. Additionally, it is involved in important regulatory mechanisms of the innate and adaptive immune system. ${ }^{24,25}$ Current data demonstrates that vitamin $\mathrm{D}$ affects the expression of more than 200 different genes.

Vitamins D2 and D3 are hydroxylated in the liver by 25-hydroxylase enzymes, forming 25-hydroxyvitamin $\mathrm{D}$ or calcidiol [25(OH)D]. In the renal tubules, $25(\mathrm{OH}) \mathrm{D}$ is hydroxylated by $1 \alpha$-hydroxylase (CYP27B1) enzymes in 1,25-dihydroxyvitamin D $\left[1,25(\mathrm{OH})_{2} \mathrm{D}\right]$, calcitriol, the biologically active form of vitamin $\mathrm{D}$, that binds to nuclear vitamin $\mathrm{D}$ receptor (VDR) in target tissues. Vitamin D receptors are widely expressed in more than 30 tissues and organs. The enzyme $1 \alpha$-hydroxylase is also expressed in extrarenal organs, including gastrointestinal tract, skin, blood vessels, mammary epithelial cells, osteoblasts and osteoclasts. ${ }^{8}$

Calcidiol or $25(\mathrm{OH}) \mathrm{D}$ is the serum metabolite that should be measured to determine the overall state of vitamin $\mathrm{D}$, since it represents a major storage form of the substance. This circulating form is biologically inactive; it has a half-life of 2-3 weeks and levels about 1,000 times higher than those of $1,25(\mathrm{OH})_{2} \mathrm{D}$. More than $95 \%$ of measurable $25(\mathrm{OH}) \mathrm{D}$ serum levels correspond to $25(\mathrm{OH}) \mathrm{D} 3$.

Calcitriol or $1,25(\mathrm{OH})_{2} \mathrm{D}$ locally produced in tissues such as breast, colon and prostate regulates several genes involved in cell proliferation, differentiation, apoptosis and angiogenesis. This explains the recent association of vitamin $\mathrm{D}$ deficiency with an increased risk of malignancies in those organs. Calcitriol produced in the kidneys reduces renin production and stimulates insulin secretion by pancreatic $\beta$ cells. ${ }^{8}$ Several skin functions are regulated by $1,25(\mathrm{OH})_{2} \mathrm{D}$ and / or its receptor, among which: keratinocytes proliferation inhibition and their differentiation stimulation - including barrier permeability formation - and promotion of innate immunity and hair follicle's cycle. ${ }^{26}$

Vitamin D insufficiency and deficiency represent a resurgent global health problem. Changes in lifestyle that have occurred in recent decades, as reduced sun exposure due to indoor-working, use of protective clothing and use of sunscreen, largely explain this vitamin deficiency. ${ }^{27}$ Insufficient consumption of foods rich in vitamin $\mathrm{D}$ and its precursors is an aggravating factor. ${ }^{28}$ There are groups at greater risk of vitamin D non-sufficiency, including women, African-Americans and individuals with increased body mass index (BMI) (Chart 2). ${ }^{24,29}$ The unquestionable benefits of using sunscreen are currently confronted by an intense debate that questions the role of photoprotection in vitamin D deficiency increasingly found in our times.

Melanin acts as a natural sunscreen and 
decreases the production of vitamin D in human skin. Individuals with a more pigmented skin require a longer sun exposure to produce the same amount of vitamin D compared to those with fair complexions. ${ }^{8}$

In intertropical zones (between latitudes $23.5^{\circ} \mathrm{N}$ and $23.5^{\circ} \mathrm{S}$ ), UVB rays are more intense and vitamin D synthesis is possible throughout the year. In temperate zones $\left(23.5^{\circ}-66.5^{\circ}\right)$, people lack sufficient UVB for vitamin $\mathrm{D}$ synthesis for 1 month during the year, while those closer to the poles do not get enough UVB radiation for most of the year. ${ }^{8,30,31}$ Vitamin D synthesis is also influenced by the season of the year, with a seasonal decline occurring in winter..$^{32}$ Studies have shown a prevalence of vitamin $\mathrm{D}$ below $10 \mathrm{mg} / \mathrm{ml}$ ranging from 0 to $32 \%$ in adolescents, depending on latitude and season. ${ }^{33}$

There were more papers published on vitamin $\mathrm{D}$ in the $21^{\text {st }}$ Century than about any other vitamin, reflecting the massive expansion of this field of research. Adequate levels of vitamin D have been associated with reduced risk of developing different types of cancer, bacterial infections, rheumatoid arthritis, Crohn's disease, periodontal disease, multiple sclerosis, asthma, atopic dermatitis, type 1 diabetes, metabolic syndrome, cardiovascular diseases, stroke, peripheral artery disease, hypertension, chronic kidney disease, muscle weakness, cognitive impairment, Alzheimer's disease, depression and premature death. ${ }^{28}$

Despite the numerous studies in progress, there is no consensus about the optimal serum levels of vitamin D. Calcidiol levels required for bone health are generally established by evaluating the level from

CHART 2: Risk factors for vitamin D deficiency or insufficiency

Absence of sun exposure
Skin pigmentation
Type of clothing (veils, scarfs, etc.)
Sunscreen use
Obesity
Newborns, preschoolers, elderly
Institutionalized persons
Multiple gestations at short intervals
Liver diseases
Malabsorption, short intestine
Drugs (for instance, rifampicin, glucocorticoids, anticon-
vulsants)
Low socio-economic status
Malnourishment and protein deficiency
Atmospheric pollution

which the compensatory elevation of serum parathyroid hormone (PTH) begins. This point varied depending on the population studied - approximately between 12 and $30 \mathrm{ng} / \mathrm{ml}$. However, interlaboratory variations can influence the apparently desired serum levels of $25(\mathrm{OH}) \mathrm{D}$. The range of values adopted by The Endocrine Society are described in chart $3 .^{34,35}$

Taking into account the physiology of vitamin $\mathrm{D}$, it could be presumed that the prevalence of its deficiency would be low in sunny countries like Brazil. However, there is a high prevalence of this hypovitaminosis even in tropical zones. ${ }^{32}$ Hypovitaminosis D is a widespread problem, present in all age groups in developing countries. It is one of the most prevalent health problems in childhood, along with infectious diseases and malnutrition. This hypovitaminosis is highly prevalent in China, Mongolia, Sub-Saharan Africa, the Middle East and Latin America, especially in children, women and the elderly. In China and Mongolia, it affects more than $50 \%$ of children. ${ }^{8}$

A study conducted in Brazil with 136 adolescents - inhabitants of the countryside of São Paulo (latitude $23^{\circ} \mathrm{S}$ ) - found vitamin D insufficiency in $60 \%$ of them. The authors suggest that this is predominantly due to a low vitamin $\mathrm{D}$ intake in this group. This finding is disturbing, since the teenage years are critical for bone mass formation. The same study found that only $14 \%$ of adolescents consume the daily requirement of vitamin D and the authors proposed future actions to implement public policies that stimulate the addition of vitamin $\mathrm{D}$ to food products. ${ }^{32}$

Also in Brazil, the evaluation of 73 young residents in a general hospital in Porto Alegre found that $57 \%$ had serum levels of $25(\mathrm{OH}) \mathrm{D}<20 \mathrm{ng} / \mathrm{ml}^{36} \mathrm{In}$ a cohort of 102 healthy elderly with an average age of 77 years in southern Brazil, $86 \%$ also had 25(OH)D below this value. ${ }^{37}$

Public health campaigns, as well as supplementing foods with vitamin $\mathrm{D}$, are efficient and affordable actions to prevent vitamin $\mathrm{D}$ deficiency. However, clinical studies are still necessary to evaluate the effect of vitamin D supplementation in classic and alternative outcomes in developing countries. ${ }^{8}$

CHART 3: Serum reference levels for 25(OH)D

\begin{tabular}{|ll} 
Vitamin D status & $25(\mathrm{OH}) \mathrm{D}$ serum concentration \\
Deficiency & $<20 \mathrm{ng} / \mathrm{ml}$ \\
Insufficiency & $20-29,9 \mathrm{ng} / \mathrm{ml}$ \\
Normal & $30-100 \mathrm{ng} / \mathrm{ml}$ \\
\hline
\end{tabular}




\section{ATOPIC DERMATITIS AND VITAMIN D}

Among the factors involved in the genesis of AD, the increasing importance of vitamin $\mathrm{D}$ deficiency in atopic patients may be highlighted. In addition to its classical role in calcium homeostasis, recent studies demonstrate the influence of vitamin $\mathrm{D}$ in immunomodulation and cell differentiation, altering the local balance of calcium and binding to nuclear receptors that regulate gene transcription. It is, furthermore, associated with keratinocyte production of antimicrobial peptides (AMP). Vitamin D and its analogues seem to play an increasing role in the management of diseases such as $\mathrm{AD}$, psoriasis, vitiligo, acne and rosacea. ${ }^{17,38-40}$

\section{RELATIONSHIP BETWEEN SERUM LEVELS OF VITAMIN D AND THE PREVALENCE/SEVERITY OF AD}

Few studies have evaluated the prevalence and severity of $\mathrm{AD}$ in vitamin $\mathrm{D}$ deficient individuals. Oren et al. (2008), in a case-control study of 290 obese patients, observed a 5-fold increase in the likelihood of $\mathrm{AD}$ in subjects with this deficiency when compared to the group sufficient in vitamin $\mathrm{D}(\mathrm{p}<0.05)$. There were no significant associations with asthma or allergic rhinitis. ${ }^{41}$

Peroni et al. (2011) evaluated the relationship between vitamin $\mathrm{D}$ and $\mathrm{AD}$ severity. The study included 37 children with AD. Serum levels of $25(\mathrm{OH}) \mathrm{D}$ were higher in patients with mild AD compared to those with moderate or severe cases ( $p$ $<0.05)$. Data suggest that vitamin $\mathrm{D}$ deficiency may be related to the severity of $\mathrm{AD} .^{17}$

A nutritional survey comparing patients with $\mathrm{AD}(\mathrm{n}=132)$ with healthy controls $(\mathrm{n}=132)$ demonstrated that patients with $\mathrm{AD}$ had a lower vitamin $\mathrm{D}$ dietary intake than the control group. However, serum vitamin $\mathrm{D}$ levels were not measured. ${ }^{42}$

It has been shown that children born from mothers with low fish or vitamin D intake during pregnancy have an increased prevalence of $\mathrm{AD}{ }^{43,44}$ In addition, cross-sectional studies demonstrate a higher prevalence of $\mathrm{AD}$ in children born during autumn and winter compared with those born in spring and summer. ${ }^{45}$

Climate and sunlight (ultraviolet radiation) influence the activity of atopic eczema. Byremo et al. (2006) randomly selected 30 children from 4-13 years of age with severe AD in Norway (subarctic / temperate climate) to settle for 4 weeks in a tropical zone and 26 children to remain in Norway. Patients were followed for 3 months. A significant reduction in clinical signs and symptoms as well as an improvement in the quality of life index was observed in the treated group after 4 weeks and 3 months ( $p<0.0005)$. Bacterial colonization by $S$. aureus was reduced in the index group in the first and third months $(p=0.001$ and $p=0.005$, respec- tively). The index group reduced the use of topical corticosteroids, but not the control group. ${ }^{46}$ Vitamin D serum levels were not considered in the study.

Similar associations were found in patients with psoriasis. Orgaz-Molina et al. (2012) reported a high prevalence $(25.6 \%)$ of vitamin D deficiency $(<20$ $\mathrm{ng} / \mathrm{ml}$ ) in 43 psoriatic patients, regardless of age, gender and severity of disease. Low levels of $25(\mathrm{OH}) \mathrm{D}$ were negatively associated with markers of inflammatory activity and BMI. ${ }^{47}$

In a case-control study with 68 psoriatic patients and 60 controls, the study group had lower serum levels of $25(\mathrm{OH}) \mathrm{D}$ than the healthy subjects $(\mathrm{p}$ $<0.05)$. There was vitamin D deficiency $(<20 \mathrm{ng} / \mathrm{ml})$ in $68 \%$ of the cases, and insufficiency $(<30 \mathrm{ng} / \mathrm{ml})$ in $97 \%$. Interestingly, the level of serum $25(\mathrm{OH}) \mathrm{D}$ had a significant negative correlation with the PASI score $(p$ $<0.001$ ), which means a possible direct relationship between the magnitude of vitamin D deficiency and disease severity. ${ }^{48}$

There are, however, many controversies. Despite the positive association between hypovitaminosis $\mathrm{D}$ and increased prevalence or severity of $\mathrm{AD}$ demonstrated in the aforementioned studies, several authors have found an inverse association.

Back et al. (2009) showed that the increased intake of vitamin D during childhood correlates with an increased risk of AD at 6 years of age. Pre-existing data on the daily intake of vitamin D3 in the first year of life were rescued and, through a postal questionnaire the cumulative incidence of $A D$, allergic rhinitis or asthma at 6 years of age were investigated in 123 children. AD was more prevalent in the group with the highest intake of vitamin D3, regardless of family history of atopy. ${ }^{49}$ The study sample, however, as the author points out, was small and more research is needed to support this association.

Breastfeeding in the first four months of life was shown to reduce the risk of childhood eczema at 4 years of age. ${ }^{50}$ Breastfeeding usually implies in low intake of vitamin D3, while replacement with infant formula and dairy drinks with cereal are fortified with vitamin D3, providing a considerably higher intake. ${ }^{49}$ Corroborating this association, Milner et al. (2004) evaluated more than 8,000 patients and demonstrated that early infant multivitamin supplementation (in the first 6 months of life) was associated with an increased risk of food allergies and asthma in black children. ${ }^{51} \mathrm{~A}$ large cohort study in Finland showed that vitamin D supplementation during the first year of life was associated with a higher prevalence of atopy and allergic rhinitis at 31 years of age. ${ }^{52}$

However, data on vitamin D dietary intake and higher prevalence of $\mathrm{AD}$ should be taken with caution, especially regarding the first year of life, a time 
when there is an increased intestinal permeability. The increase in food sensitization and higher incidence of atopy in children exposed to foods other than breast milk is attributed to this increased permeability. Could there be a significant relationship between the serum levels of vitamin D and the increased prevalence of $\mathrm{AD}$ in children with a higher dietary intake of this substance at an early age? Or is this the result of an early exposure to various antigens associated with increased intestinal permeability, a well-known predisposing factor to atopy?

The maternal vitamin D profile during pregnancy was also important. Children whose mothers had increased serum levels of $25(\mathrm{OH}) \mathrm{D}$ had a higher risk of eczema at 9 months and asthma at 9 years old. ${ }^{53}$

Chiu et al. (2013), in one of the most recent published studies on the association between vitamin $\mathrm{D}$ and AD, evaluated 94 children from 1-16 years old living in urban Milwaukee (USA). There was no statistically significant correlation between vitamin $\mathrm{D}$ status and the severity of AD. Interestingly, children with mild AD had serum levels of $25(\mathrm{OH}) \mathrm{D}$ lower than groups with moderate and severe disease, although this difference was not statistically significant. ${ }^{54}$

From the considerations above, we can observe that this topic is very controversial. Sometimes vitamin $\mathrm{D}$ is considered a protective factor, sometimes a risk factor for AD. However it seems that there is, at least quantitatively, a predominance of papers that point to an inverse association between serum levels of vitamin $\mathrm{D}$, nutritional intake or sun exposure and the prevalence and severity of AD. Not only 25(OH)D but VDR polymorphism as well has been investigated.

Heine et al. (2013) showed that, in patients with severe AD, VDR gene polymorphisms are significantly over-represented. The authors investigated the frequency of four of this gene's most common polymorphisms in patients with AD and their potential functional significance. VDR haplotypes were found more often in patients with severe AD. This finding suggests that VDR contributes to the control of $A D$ and may have effects on the regulation of epidermal barrier function and / or local immune response. VDR can reduce the expression of proinflammatory cytokines such as IL -6 and TNF- $\alpha$ in myeloid innate immune cells and keratinocytes, and inhibit the maturation of dendritic cells. VDR gene variations may result in altered responsiveness to vitamin D in inflammatory conditions. The identified haplotype was previously associated with asthma in independent cohorts. Since this haplotype also occurs with high frequency, in healthy non-atopic individuals, its significance in severe phenotype cases should be considered more as that of a cofactor, which requires one or more environmental and / or genetic additional cofactors. ${ }^{55}$

\section{BIOLOGICAL PLAUSIBILITY: ASSOCIATION BETWEEN VITAMIN D AND ATOPIC DERMATI- TIS}

There are several biologically plausible explanations for the inverse relationship between vitamin $\mathrm{D}$ serum levels and the prevalence of $\mathrm{AD}$, in particular with the severity of this disease.

\section{VITAMIN D: IMMUNE REGULATION AND ANTIBACTERIAL ACTIVITY}

Vitamin D is involved in important regulatory mechanisms of the innate and adaptive immune system. ${ }^{17}$ VDR has been found in a variety of cells, including keratinocytes, and numerous cells of the immune system. ${ }^{6}$

$1,25(\mathrm{OH})_{2} \mathrm{D}$ inhibits the proliferation of $\mathrm{T}$ cells (particularly Th1 cells capable of producing interferon-gamma, IL-2 and activating macrophages) and Th17 cells (capable of producing IL-17 and IL-22)..$^{56,57,58}$ In addition, regulatory $\mathrm{CD} 4+/ \mathrm{CD} 25+\mathrm{T}$ cells are amplified by $1,25(\mathrm{OH})_{2} \mathrm{D}$, with consequent stimulation of IL-10 production, which further reduces the development of Th1 and Th17 cells. ${ }^{59,60}$

Vitamin D affects the production of AMP, endogenous antibiotics that play a central role in the pathogenesis of many inflammatory skin diseases such as $\mathrm{AD}$ and psoriasis. ${ }^{25}$ In vitro studies show that $1,25(\mathrm{OH})_{2} \mathrm{D}$ induces the expression of cathelicidin - a broad spectrum AMP - in keratinocytes, resulting in an increased antimicrobial activity against $S$. aureus and selective reduction in the expression of cutaneous lymphocyte -associated antigens. ${ }^{61}$ A study observed a significant increase in cathelicidin levels in skin lesions of 14 patients with moderate to severe $\mathrm{AD}$, after treatment with 4,000 IU of oral vitamin D for 21 days. The average value went from $3.53 \mathrm{RCU}$ (relative copy units) to $23.91 \mathrm{RCU}$ after supplementation ( $\mathrm{p}<$ 0.01 ). The skin of patients without $A D$ and the healthy skin of AD patients also showed increased levels of cathelicidin, although not significant ( $p>0.05)$. These results suggest that vitamin $\mathrm{D}$ oral supplementation significantly induces the production of cathelicidin in injured skin of $\mathrm{AD}$ patients. ${ }^{62}$ When monocytes and macrophages are stimulated by an infectious agent, there is an increase in the expression of VDR and $1 \alpha-$ hydroxylase, augmenting the conversion of $25(\mathrm{OH}) \mathrm{D}$ in $1,25(\mathrm{OH})_{2} \mathrm{D}$ and therefore increasing the expression of cathelicidin. ${ }^{8}$

Büchau et al. (2009) showed that the low expression of AMP observed in AD skin samples is associated with an overexpression of B-cell lymphoma (Bcl)-3 gene. Biopsies of skin lesions showed more Bcl-3 mRNA than healthy skin biopsies. After vitamin $D$ supplementation there was less Bcl-3 expression $(p=0.077){ }^{63}$

UVB phototherapy has been successfully used, for many years, in AD treatment. ${ }^{40}$ Recent studies sug- 
gest that UVB-induced vitamin D is a possible mediator of improvement in the symptoms and severity of the disease. In a study of patients with $\mathrm{AD}(\mathrm{n}=18)$, psoriasis $(n=18)$ and controls $(n=15)$ exposed to narrowband UVB phototherapy, biopsies of lesions in AD patients showed more AMP than in the control group. ${ }^{64}$

Matheson et al. (2010) demonstrated that individuals with vitamin $\mathrm{D}$ deficiency had a significant increase in the risk of carrying methicillin-resistant $S$. aureus (MRSA).${ }^{65}$ It is unclear, however, whether vitamin $\mathrm{D}$ supplementation can reduce MRSA colonization.

\section{VITAMIN D AND THE SKIN BARRIER FUNC- TION}

Calcitriol $\left[1,25(\mathrm{OH})_{2} \mathrm{D}\right]$ is known to modulate the proliferation and differentiation of keratinocytes. ${ }^{5}$ For this reason, vitamin D3 analogues have been used to normalize the hyperproliferation present in psoriatic skin. ${ }^{24}$

In experiments with mice, Hong et al. (2008) observed a faster recovery of the skin barrier in the group treated with narrowband UVB phototherapy, observing higher histological levels of filaggrin and involucrin in this population. Phototherapy-induced vitamin D was considered responsible for accelerating the epidermal barrier recovery. ${ }^{66}$

Keratinocytes express high levels of $1 \alpha$-hydroxylase. The product of this enzyme, $1,25(\mathrm{OH})_{2} \mathrm{D}$ promotes in vitro differentiation of keratinocytes. In mice that lack this enzyme, there is a decrease of involucrin, filaggrin and loricrin - keratinocyte differentiation markers - essential for the cornified envelope formation. Mice that are defective in VDR have an increased transepidermal water-loss because of the epidermal barrier breakage. $1,25(\mathrm{OH})_{2} \mathrm{D}$ was found to be essential for normal epidermal differentiation, probably by inducing proteins and mediating calcium signaling in the epidermis, steps that are necessary for the generation and maintenance of the skin barrier. ${ }^{67}$

Studies on psoriasis indicate that the topical treatment with calcipotriol, $1,25(\mathrm{OH})_{2} \mathrm{D}$ analog, increases VDR expression in keratinocytes. Effects of calcipotriol in epidermal keratinocytes proliferation and differentiation were more pronounced than its effects on dermic inflammation. ${ }^{68}$

Russel (2012) evaluated the association between $25(\mathrm{OH}) \mathrm{D}$ serum levels and stratum corneum conductance in 83 female patients from 18 to 45 years old. The author found smaller amounts of vitamin $\mathrm{D}$ in patients with lower levels of skin hydration $(p=0.02) .{ }^{24}$

Observations that topical calcineurin inhibitors may partially correct the barrier defect in $\mathrm{AD}$ and that gentamicin can restore the production of filaggrin chains provide additional evidence of the complex relation between epidermal barrier and immune system. ${ }^{69}$

\section{THERAPEUTIC ROLE OF VITAMIN D SUPPLE- MENTATION IN ATOPIC DERMATITIS}

Confirming the data obtained from observational studies, recent clinical trials suggest a therapeutic role for vitamin $\mathrm{D}$ supplementation in the treatment of $\mathrm{AD} .{ }^{40}$ Sidbury et al. (2008) conducted a randomized double-blind study in which 11 children aged 2-13 years received 1,000 IU of vitamin D or placebo during one month. Four of the five children who received vitamin D showed improvement, while only one of the six children in the control group improved $(\mathrm{p}=$ 0.04). ${ }^{70}$ The small number of participants limits the power of the study.

Amestejani et al. (2012) published a randomized, double-blind, placebo-controlled trial in which 30 patients received vitamin D 1,600 IU / day and 30 patients received placebo. After 60 days, the group treated with vitamin D improved significantly, regardless of the initial severity of $\mathrm{AD}(\mathrm{p}<0.05)$. In the placebo group, the improvement was not significant ( $p>0.05)$. Serum levels of $25(\mathrm{OH}) \mathrm{D}$ in the treatment group were significantly higher than baseline values $(p=0.001)$. The study results suggest that vitamin $D$ supplementation improves AD. ${ }^{6}$

Another study evaluated the effects of vitamins $\mathrm{D}$ and $\mathrm{E}$ supplementation in clinical manifestations of AD. Forty-five patients with AD were included in a randomized, double blind, placebo-controlled study. Clinical improvement was evaluated using SCORAD, which showed significant reduction after 60 days in the groups receiving vitamin $\mathrm{D}$ or $\mathrm{E}$, or both vitamins $(p=0.004){ }^{71}$

\section{CONCLUSIONS}

Hypovitaminosis D has emerged as a potential risk factor for infections, allergic disorders and chronic diseases. The possible consequences of hypovitaminosis $\mathrm{D}$ high prevalence are worrisome, given the recognition of various non-skeletal physiological actions of vitamin D. The need for public healthcare advertising campaigns warning about the importance of vitamin D is pressing, especially in countries where there is a high prevalence of hypovitaminosis.

It is necessary to explain with due emphasis to the population, the harmful effects of unprotected sunlight exposure and the actual impact of sunscreen use in vitamin D production, since it is common that non-dermatologists suggest this practice, which could, in the future, reduce the prevalence of hypovitaminosis D and, conversely, increase the incidence of cutaneous neoplasms.

There are several limitations in vitamin D studies, such as the lack of standardization for its serum level's measurement, a wide range of reference values used to define deficiency and insufficiency and hap- 
hazard measurements of vitamin D in a given period, which may not reflect the real status of the patient. ${ }^{8}$

The role of vitamin D and its metabolites in pre and postnatal maturation of lymphoid and epithelial tissues, involved in the development of cutaneous and respiratory allergic manifestations, remains controversial suggesting both strengthening and protecting mechanisms. ${ }^{6}$ Further studies are needed to clarify this discussion. Any conclusion would still be premature.

There are encouraging results regarding the therapeutic use of adjuvant vitamin $\mathrm{D}$ in AD. They must, meanwhile, be regarded with caution. Randomized controlled trials adequately designed in order to establish optimal dose, duration and effect of vitamin D supplementation in various health out- comes are still needed. In the field of $\mathrm{AD}$, future studies should investigate the optimal levels of vitamin D necessary to maintain cutaneous health and their correlation to serum levels, as well as clarify the role of vitamin D in dry skin.

Vitamin D can be on the opposite side of several known $\mathrm{AD}$ associations, such as the protection afforded by breastfeeding, low bone mineral density in patients with $\mathrm{AD}$, clinical improvement after sun exposure and the benefits provided by phototherapy. ${ }^{50,46,72,73}$

Vitamin D decreases the susceptibility to infection in patients with $\mathrm{AD}$ and controls the local inflammatory immune response, representing a promising tool for the understanding and treatment of this chronic inflammatory disease. ${ }^{7}$

\section{REFERENCES}

1. Palmer $\mathrm{CN}$, Irvine $\mathrm{AD}$, Terron-Kwiatkowski $\mathrm{A}$, Zhao $\mathrm{Y}$, Liao $\mathrm{H}$, Lee SP, et al. Common loss-of-function variants of the epidermal barrier protein filaggrin are a major predisposing factor for atopic dermatitis. Nat Genet. 2006;38:441-6

2. Spergel JM. Epidemiology of atopic dermatitis and atopic march in children. Immunol Allergy Clin North Am. 2010;30:269-80.

3. Zeppa L, Bellini V, Lisi P. Atopic dermatitis in adults. Dermatitis. 2011;22:40-6.

4. Eichenfield LF, Ellis CN, Mancini AJ, Paller AS, Simpson EL. Atopic dermatitis: epidemiology and pathogenesis update. Semin Cutan Med Surg. 2012;31:S3-5.

5. Boguniewicz M, Leung DY. Atopic dermatitis: a disease of altered skin barrier and immune dysregulation. Immunol Rev. 2011;242:233-46.

6. Amestejani M, Salehi BS, Vasigh M, Sobhkhiz A, Karami M, Alinia H, et al. Vitamin $\mathrm{D}$ supplementation in the treatment of atopic dermatitis: a clinical trial study. $J$ Drugs Dermatol. 2012;11:327-30.

7. Bouillon R. Vitamin D and extraskeletal health. In: Mulder JE, editor. UpToDate. 2013 [cited 2013 Mar 10]. Avaialable from: http://www.uptodate.com

8. Arabi A, El Rassi R, El-Hajj Fuleihan G. Hypovitaminosis D in developing countriesprevalence, risk factors and outcomes. Nat Rev Endocrinol. 2010:6:550-61.

9. Ginde AA, Liu MC, Camargo CA Jr. Demographic differences and trends of vitamin D insufficiency in the US population, 1988-2004. Arch Intern Med. 2009;169:626-32.

10. Holick MF. Vitamin D deficiency. N Engl J Med. 2007;357:266-81.

11. Kapoor R, Menon C, Hoffstad O, Bilker W, Leclerc P, Margolis DJ. The prevalence of atopic triad in children with physician-confirmed atopic dermatitis. J Am Acad Dermatol. 2008;58:68-73.

12. Boguniewicz M, Schmid-Grendelmeier P, Leung DY. Atopic dermatitis. J Allergy Clin Immunol. 2006;118:40-3.

13. Amaral CS, March Mde F, Sant'Anna CC. Quality of life in children and teenagers with atopic dermatitis. An Bras Dermatol. 2012;87:717-23.

14. Weber MB, Lorenzini D, Reinehr CP, Lovato B. Assessment of the quality of life of pediatric patients at a center of excellence in dermatology in southern Brazil. An Bras Dermatol. 2012;87:697-702.

15. Kiebert G, Sorensen SV, Revicki D, Fagan SC, Doyle JJ, Cohen J, et al. Atopic dermatitis is associated with a decrement in health-related quality of life. Int $\mathrm{J}$ Dermatol. 2002;41:151-8.

16. Hanifin JM, Rajka G. Diagnostic features of atopic dermatitis. Acta Dermatol Venereol. 1980:92:44-7.

17. Peroni DG, Piacentini GL, Cametti E, Chinellato I, Boner AL. Correlation between serum 25-hydroxyvitamin $\mathrm{D}$ levels and severity of atopic dermatitis in children. $\mathrm{Br}$ J Dermatol. 2011;164:1078-82.

18. Addor FA, Aoki V. Skin barrier in atopic dermatitis. An Bras Dermatol. 2010;85:184-94

19. Petry V, Bessa GR, Poziomczyck CS, Oliveira CF, Weber MB, Bonamigo RR, et al. Bacterial skin colonization and infections in patients with atopic dermatitis. An Bras Dermatol. 2012;87:729-34.
20. Schneider L, Tilles S, Lio P, Boguniewicz M, Beck L, LeBovidge J, et al. Atopic dermatitis: a practice parameter update 2012. J Allergy Clin Immunol. 2013;131:2959.e1-27.

21. Leung DYM, Eichenfield LF, Boguniewicz M. Atopic Dermatitis (Atopic Eczema). In Wolff K, Goldsmith LA, Katz SI, Gilchrest BA, Paller AS, Leffell DJ, editors. Fitzpatrick's Dermatology in General Medicine. McGraw-Hill; 2008. p. 146-158.

22. Dold S, Wjst M, von Mutius E, Reitmeir P, Stiepel E. Genetic risk for asthma, allergic rhinitis, and atopic dermatitis. Arch Dis Child. 1992;67:1018-22.

23. De Benedetto A, Rafaels NM, McGirt LY, Ivanov Al, Georas SN, Cheadle C, et al. Tight junction defects in patients with atopic dermatitis. J Allergy Clin Immunol. 2011;127:773-86.e1-7

24. Russell M. Assessing the relationship between vitamin D3 and stratum corneum hydration for the treatment of xerotic skin. Nutrients. 2012;4:1213-8.

25. Reinholz M, Schauber J. Vitamin D and innate immunity of the skin. Dtsch Med Wochenschr. 2012;137:2385-9.

26. Bikle DD. Vitamin D metabolism and function in the skin. Mol Cell Endocrinol 2011;347:80-9.

27. Zittermann A, Prokop S, Gummert JF, Borgermann J. Safety Issues of Vitamin D Supplementation. Anticancer Agents Med Chem. 2013:13:4-10.

28. Glade MJ. Vitamin D: Health Panacea or false Prophet? Nutrition. 2013;29:37-41.

29. Gupta A, Bush A, Hawrylowicz C, Saglani S. Vitamin D and asthma in children. Paediatr Respir Rev. 2012;13:236-43

30. Tavera-Mendoza LE, White JH. Cell defenses and the sunshine vitamin. Sci Am. 2007;297:62-5, 68-70, 72.

31. Mithal A, Wahl DA, Bonjour JP, Burckhardt P, Dawson-Hughes B, Eisman JA, et al. Global vitamin D status and determinants of hypovitaminosis D. Osteoporos Int 2009;20:1807-20

32. Peters BS, dos Santos LC, Fisberg M, Wood RJ, Martini LA. Prevalence of vitamin D insufficiency in Brazilian adolescents. Ann Nutr Metab. 2009;54:15-21.

33. Tylavsky FA, Ryder KA, Lyytikäinen A, Cheng S. Vitamin D, parathyroid hormone, and bone mass in adolescents. J Nutr. 2005;135:2735S-8S.

34. Lips P. Which circulating level of 25 -hydroxyvitamin D is appropriate? J Steroid Biochem Mol Biol. 2004;89-90:611-4.

35. Holick MF, Binkley NC, Bischoff-Ferrari HA, Gordon CM, Hanley DA, Heaney RP, et al. Evaluation, treatment, and prevention of vitamin D deficiency: an Endocrine Society clinical practice guideline. J Clin Endocrinol Metab. 2011;96:1911-30.

36. Premaor M0, Paludo P, Manica D, Paludo AP, Rossatto ER, Scalco R, et al. Hypovitaminosis $D$ and secondary hyperparathyroidism in resident physicians of a general hospital in southern Brazil. J Endocrinol Invest. 2008;31:991-5.

37. Scalco R, Premaor MO, Fröehlich PE, Furlanetto TW. High prevalence of hypovitaminosis $D$ and secondary hyperparathyroidism in elders living in nonprofit homes in South Brazil. Endocrine. 2008;33:95-100.

38. Miller J, Gallo RL. Vitamin D and innate immunity. Dermatol Ther. 2010;23:13-22. 
39. van Etten E, Mathieu C. Immunoregulation by 1,25-dihydroxyvitamin D3: basic concepts. J Steroid Biochem Mol Biol. 2005;97:93-101.

40. Mutgi K, Koo J. Update on the Role of systemic vitamin D in atopic dermatitis. Pediatr Dermatol. 2013;30:303-7.

41. Oren E, Banerji A, Camargo CA Jr. Vitamin D and atopic disorders in an obese population screened for vitamin D deficiency. J Allergy Clin Immunol. 2008;121:533-4.

42. Solvoll K, Soyland E, Sandstad B, Drevon CA. Dietary habits among patients with atopic dermatitis. Eur J Clin Nutr. 2000;54:93-7.

43. Willers SM, Devereux G, Craig LC, McNeill G, Wijga AH, Abou El-Magd W, et al. Maternal food consumption during pregnancy and asthma, respiratory and atopic symptoms in 5-year-old children. Thorax. 2007;62:773-9.

44. Miyake Y, Sasaki S, Tanaka K, Hirota Y. Dairy food, calcium and vitamin D intake in pregnancy, and wheeze and eczema in infants. Eur Respir J. 2010;35:1228-34.

45. Kuzume K, Kusu M. Before-birth climatologic data may play a role in the development of allergies in infants. Pediatr Allergy Immunol. 2007;18:281-7.

46. Byremo G, Rød G, Carlsen KH. Effect of climatic change in children with atopic eczema. Allergy. 2006;61:1403-10.

47. Orgaz-Molina J, Buendía-Eisman A, Arrabal-Polo MA, Ruiz JC, Arias-Santiago S. Deficiency of serum concentration of 25-hydroxyvitamin D in psoriatic patients: a case-control study. J Am Acad Dermatol. 2012;67:931-8

48. Ricceri F, Pescitelli L, Tripo L, Prignano F.. Deficiency of serum concentration of 25hydroxyvitamin $\mathrm{D}$ correlates with severity of disease in chronic plaque psoriasis. $J$ Am Acad Dermatol. 2013:68:511-2.

49. Bäck 0, Blomquist HK, Hernell 0, Stenberg B. Does vitamin D intake during infancy promote the development of atopic allergy? Acta Derm Venereol. 2009;89:28-32

50. Kull I, Böhme M, Wahlgren CF, Nordvall L, Pershagen G, Wickman M. Breast-feeding reduces the risk for childhood eczema. J Allergy Clin Immunol. 2005;116:657-61.

51. Milner JD, Stein DM, McCarter R, Moon RY. Early infant multivitamin supplementation is associated with increased risk for food allergy and asthma. Pediatrics. 2004;114:27-32.

52. Hyppönen E, Sovio U, Wjst M, Patel S, Pekkanen J, Hartikainen AL, et al. Infant vitamin d supplementation and allergic conditions in adulthood: northern Finland birth cohort 1966. Ann N Y Acad Sci. 2004;1037:84-95.

53. Gale CR, Robinson SM, Harvey NC, Javaid MK, Jiang B, Martyn CN, et al. Maternal vitamin D status during pregnancy and child outcomes. Eur J Clin Nutr. 2008;62:68-77

54. Chiu YE, Havens PL, Siegel DH, Ali 0, Wang T, Holland KE, et al. Serum 25-hydroxyvitamin $\mathrm{D}$ concentration does not correlate with atopic dermatitis severity. J Am Acad Dermatol. 2013;69:40-6.

55. Heine G, Hoefer N, Franke A, Nöthling U, Schumann RR, Hamann L, et al. Association of vitamin $\mathrm{D}$ receptor gene polymorphisms with severe atopic dermatitis in adults. Br J Dermatol. 2013;168:855-8.

56. Rigby WF, Stacy T, Fanger MW. Inhibition of T lymphocyte mitogenesis by 1,25dihydroxyvitamin D3 (calcitriol). J Clin Invest. 1984;74:1451-5.

57. Lemire JM, Archer DC, Beck L, Spiegelberg HL. Immunosuppressive actions of 1,25-dihydroxyvitamin D3: preferential inhibition of Th1 functions. J Nutr. 1995;125:1704S-1708S

58. Daniel C, Sartory NA, Zahn N, Radeke HH, Stein JM. Immune modulatory treatment of trinitrobenzene sulfonic acid colitis with calcitriol is associated with a change of a T helper (Th) 1/Th17 to a Th2 and regulatory T cell profile. J Pharmacol Exp Ther. 2008;324:23-33

59. Penna G, Adorini L. 1 Alpha,25-dihydroxyvitamin D3 inhibits differentiation, maturation, activation, and survival of dendritic cells leading to impaired alloreactive $T$ cell activation. J Immunol. 2000;164:2405-11.

60. Griffin MD, Xing N, Kumar R. Vitamin D and its analogs as regulators of immune activation and antigen presentation. Annu Rev Nutr. 2003;23:117-45.

61. Schauber J, Dorschner RA, Yamasaki K, Brouha B, Gallo RL. Control of the innate epithelial antimicrobial response is cell-type specific and dependent on relevant microenvironmental stimuli. Immunology. 2006;118:509-19.

62. Hata TR, Kotol P, Jackson M, Nguyen M, Paik A, Udall D, et al. Administration of oral vitamin $\mathrm{D}$ induces cathelicidin production in atopic individuals. J Allergy Clin Immunol. 2008;122:829-31.

63. Büchau AS, MacLeod DT, Morizane S, Kotol PF, Hata T, Gallo RL. Bcl-3 acts as an innate immune modulator by controlling antimicrobial responses in keratinocytes. J Invest Dermatol. 2009;129:2148-55.
64. Vähävihu K, Ala-Houhala M, Peric M, Karisola P, Kautiainen $\mathrm{H}$, Hasan $\mathrm{T}$, et al. Narrowband ultraviolet B treatment improves vitamin D balance and alters antimicrobial peptide expression in skin lesions of psoriasis and atopic dermatitis. $\mathrm{Br} \mathrm{J}$ Dermatol. 2010;163:321-8.

65. Matheson EM, Mainous AG 3rd, Hueston WJ, Diaz VA, Everett CJ. Vitamin D and methicillin-resistant Staphylococcus aureus nasal carriage. Scand J Infect Dis. 2010;42:455-60.

66. Hong SP, Kim MJ, Jung MY, Jeon H, Goo J, Ahn SK, et al. Biopositive effects of low-dose UVB on epidermis: coordinate upregulation of antimicrobial peptides and permeability barrier reinforcement. J Invest Dermatol. 2008;128:2880-7.

67. Bikle DD, Chang S, Crumrine D, Elalieh H, Man MQ, Dardenne 0, et al. Mice lacking $250 \mathrm{HD}$ 1alpha-hydroxylase demonstrate decreased epidermal differentiation and barrier function. J Steroid Biochem Mol Biol. 2004;89-90:347-53.

68. Reichrath J, Müller SM, Kerber A, Baum HP, Bahmer FA. Biologic effects of topical calcipotriol (MC 903) treatment in psoriatic skin. J Am Acad Dermatol. 1997;36:19-28

69. Jung T, Stingl G. Atopic dermatitis: therapeutic concepts evolving from new pathophysiologic insights. J Allergy Clin Immunol. 2008;122:1074-81.

70. Sidbury R, Sullivan AF, Thadhani RI, Camargo CA Jr. Randomized controlled trial of vitamin D supplementation for winter-related atopic dermatitis in Boston: a pilot study. Br J Dermatol. 2008;159:245-7.

71. Javanbakht MH, Keshavarz SA, Djalali M, Siassi F, Eshraghian MR, Firooz A, et al. Randomized controlled trial using vitamins $E$ and $D$ supplementation in atopic dermatitis. J Dermatolog Treat. 2011;22:144-50.

72. Haeck I, van Velsen S, de Bruin-Weller M, Bruijnzeel-Koomen C. Bone mineral density in patients with atopic dermatitis. Chem Immunol Allergy. 2012;96:96-9.

73. Tintle S, Shemer A, Suárez-Fariñas M, Fujita H, Gilleaudeau P, Sullivan-Whalen M, et al. Reversal of atopic dermatitis with narrow-band UVB phototherapy and biomarkers for therapeutic response. J Allergy Clin Immunol. 2011;128:583-93.e1-4

MAILING ADDRESS:
Kleyton de Carvalho Mesquita
SGAN 605, Avenida L2 Norte
70840 - 901 - Brasília - DF
Brazil
E-mail: kleyton.mesquita@gmail.com

How to cite this article: Mesquita KC, Igreja ACSM, Costa IMC. Atopic dermatitis and vitamin D: facts and controversies. An Bras Dermatol. 2013;88(6):945-53. 